\title{
Electrophysiological analysis of the cognitive component of social creativity in young males and females with different individual characteristics
}

\author{
Oksana S. Saakyan \\ South Federal University, Rostov-on-Don, Russia \\ Corresponding author. E-mail: oksana_saakyan@mail.ru
}

\begin{abstract}
This article sets forth the problem of studying social creativity from the psychophysiological perspective. Presented here are the first experimental records of studying the cognitive component of social activity. This article describes the peculiar hemispheric activity during the resolution of interpersonal problems by students of different individual peculiarities and professional achievement levels. The author shows that when the solution to a verbal divergent task by young males and females of high creativity and professional achievement is reached, the frequency-spatial EEG indexes are higher in the parietal and frontal brain regions. In the solution of a convergent task, these indexes are higher in the frontal, central and cervical brain zones. In case of young males and females of low creativity and average and low levels of professional achievement, the solution of a convergent task is accompanied by increased EEG power in the central, frontal, parietal zones of both hemispheres.

Thus, the assessment of the psychophysiological mechanisms of the cognitive component in social activity has shown that a definite picture of hemispheric activation stipulates the peculiarities of divergent and convergent thinking in young males and females of various levels of creativity and professional success.

This difference, revealed at the initial stage of investigation, demands a deeper study of the phenomenon of social creativity in the professional training of a personality that is inclusive of this personality's individual peculiarities.
\end{abstract}

Keywords: social creativity, creativity level, EEG power peculiarities, lateral arrangement profile (LAP), gender

\section{Introduction}

The changes observed in modern Russian economic, political, and social domains are naturally reflected in those challenges faced by the higher education system of today. The future young expert should now be able to solve nonconventional creative problems in the professional sphere, thus showing competitive power at the 
labor market. Much depends upon social creativity that helps one overcome barriers, stereotypes, and behavioral patterns, to modify the communications behavior repertory, and promote self-realization and self-actualization in interpersonal interactions (Osipova, 2000; Kaufman, Baer, Loomis, 2010); which are essential for so many present-day occupations.

The works of modern Russian psychologists treat social creativity as a specific mental characteristic, showing itself as an ability to give rise to new ideas in communication and to produce multiple variants of viable solutions to those problems referred to interpersonal communication (Kann, 1997; Ilyinykh, 2011; Tyurmina, 2004; Akhmetova, 2010).

Another matter of disagreement is the interconnection between gender and creativity (Runco, 1986; Abra, Valentine-French, 1991; Chan, 2005; Kaufman, 2006).

Foreign psychologists treat social creativity either as a form of social intellect (J. Guilford, R. Sternberg) or social genius (S. Grace, R. Tomassoni).

A number of authors studying social creativity have noted its components. Thus, according to A.A. Popel, social creativity includes self-actualization ability, social motivation, communicative sensitivity, and social imagination (Popel, 2005; Banyukhova, 2011).

A.Ye. Ilyinykh (2011) proposed the following structural model for social creativity. Its basic components are motivational (creative position, pursuit of self-improvement and personal growth), cognitive (verbal originality in the use of verbal means in everyday communication), communicative (employment of those communicative means that are adequate to the communicative situation), emotional (assessment of the partner's emotional state), and existential (availability of a life goal, its meaningfulness, sense of a time perspective).

As shown above, social creativity is to be understood as a complex personal characteristic that entails the recognition and analysis of the reasons and dynamics of various social situations and the ability to make effective creative decisions. It is characterized by an ability to interpret socially significant situations in an original and flexible way (Ilyinykh, 2011).

Proceeding from the position that human behavior is a synthesis of biological and social factors, one may state that the study of interpersonal communicative interaction should also be placed among the critical tasks in social psychophysiology, particularly electrophysiological communicational patterns, perception of other people's behavioral peculiarities in communication, etc.

There are few studies of psychophysiological mechanisms, specifically cerebral mechanisms underlying adequate perception of a socially significant situational context and decision-making.

\section{Method}

This research is the initial stage of a future, larger study of the psychophysiological aspects of social creativity in students with different individual peculiarities and abilities with respect to professional skills.

In our studies of social creativity's cognitive components with respect to the effective use of verbal means in communication, we utilized the social creativity model proposed by A.Ye. Ilyinykh. The basis of the study also included our pre- 
vious research of the same respondent group, which was aimed at the identification of electrical brain activity peculiarities according to the task type and personal equation.

Hence, the objective of this research is a study of the brain's electrical activity in young males and females with different creativity levels, academic achievement and lateral arrangement in solving cognitive tasks of social creativity.

The subject under examination is the EEG peculiarities in young males and females of different creativity levels, lateral arrangement profiles (LAPs), and professional achievements as they undergo verbal tests.

The test subjects were undergraduate humanists (4-5 years of studies) of the Academy of Psychology and Pedagogics at South Federal University; the sample totaled 250 people aged between 21 and 23. All the respondents were divided into groups according to their verbal creativity levels, professional achievements (scholarships, University Rector's commendations, scientific and social achievements, top results at academic research contests, etc.), lateral arrangement profiles (LAPs), and gender.

Research methods included literature analysis, psychological testing, talk method, EEG method, and expert estimations of document-supported achievements. We also traced the group since the start of their tenure at the University.

Psychodiagnostic methods included the Guilford subject use methods in the Tunik modification (to diagnose verbal creativity), as well as T.A. Bragina and N.N. Dobrokhotova's functional interhemispheric asymmetry profile determination methods.

Guilford subject use methods in the Tunik modification were applied to diagnose verbal creativity.

The results obtained by a treatment of the retrieval could be presented as three groups.

Group 1: persons demonstrating a low level of verbal creativity; results lower than the originality level $\mathrm{Or} \leq 0.81$, uniqueness level $\mathrm{Un} \leq 2$;

Group 2: persons demonstrating a middle level of verbal creativity; results within the following limits: originality level $0.82<$ Or $\leq 0.93$, uniqueness level being $2<\mathrm{Un} \leq 5$;

Group 3: persons demonstrating a high level of verbal creativity; results exceeding the originality level Or $>0.94$, uniqueness level Un $>5$.

T.A. Bragina and N.N. Dobrokhotova's functional interhemispheric asymmetry profile determination methods. These methods comprise a number of questions and estimates motor (hand, foot) and sensory (ear, eye) asymmetry with the further profiling of right, left, mixed, or ambidextrous.

Psychophysiological methods. The investigation applied the EEG (electroencephalography) method. EEG recordings were conducted according to international standards (10-20\%) consistent with the standard procedure of registering the EEG background, eye-opening and eye-closing tests. To register brain electric activity, 21 electrodes were used, a monopolar scheme with ipsilateral ear referents.

Investigation procedure description. All those who took part in the investigation were subdivided depending on gender, lateral arrangement profile (LAP), and 
academic progress level. According to LAP, the test subjects were subdivided into those representing left, right, and mixed LAPs. They were subdivided according to their academic progress level into high progress (achievements in scientific and social life, scientific publications, diplomas, scholarships), moderate progress (scientific publications, participation in conferences), and low progress (no publications, no scientific or social life) groups.

Before the EEG examination started, the test subjects were instructed on how to accomplish the verbal tasks. Two types of tasks were used in the investigation:

- verbal convergent (the test subject had to recollect proverbs about interpersonal interaction);

- verbal divergent (inventing one's own original proverb about interpersonal interaction, or a free creative search task);

The above tasks were presented during EEG recording. EEG was also marked at the beginning and end of the presentation; the signal 'test subject's reply' was also registered as this person was ready to give a reply. Test subjects' replies to verbal tasks were recorded in the study protocols. In addition, while EEG was being recorded, the test subjects were offered background tests (EO - eyes open, EC eyes closed). All the documented data on each test subject were assessed according to the factors of velocity, flexibility, originality, productivity. Next, the EEG data were analyzed. In our investigation, we used the mean time spent by the test subject to solve each given task. The time was measured as the lapse between the end of the task presentation and the 'reply' signal given by the test subject.

Each functionally relevant EEG period underwent a spectral analysis within the following frequency ranges: theta $1(4.0-6.0 \mathrm{~Hz})$, theta2 $(6.0-8.0 \mathrm{~Hz})$, alpha1 $(8.0-$ $10.5 \mathrm{~Hz})$, alpha2 $(10.5-13.0 \mathrm{~Hz})$, beta1 $(13.0-24.0 \mathrm{~Hz})$, and beta2 $(24.0-35.0 \mathrm{~Hz})$.

Mathematical treatment of the data was performed with STATISTICA 8.

\section{Results}

The electrophysiological and statistical analysis of every frequency range from theta 1 to beta 2 of each functional test in various groups of test subjects revealed a significant difference in brain area activity during the solution of the above types of test tasks depending on the personal equation.

The solution of a verbal convergent task the by test subjects of low creativity is characterized by power amplification in the occipital and frontal temporal zones of the left hemisphere $(\mathrm{O} 1, \mathrm{~T} 3)$ and the frontal temporal zone of the right hemisphere (T4) $(p<0.05)$. In those of average creativity level: anterior frontal and middle frontal zones of both hemispheres (Fp1, Fp2, F3, F4) ( p < 0.05). In those of high creativity level: anterior frontal zones of both hemispheres $(\mathrm{Fp} 1, \mathrm{Fp} 2)(\mathrm{p}<0.05)$.

While solving a verbal divergent task, the test subjects of high creativity level showed power amplification in the anterior frontal, central and parietal zones of the right hemisphere $(\mathrm{Fp} 2, \mathrm{C} 4, \mathrm{P} 4)(\mathrm{p}<0.05)$. In those of average creativity level, power amplification was evident in the occipital zones $(\mathrm{O} 2, \mathrm{O} 1, \mathrm{Oz})$. In those of low creativity level, power amplification was evident in parietal and frontal temporal zones of the left hemisphere (P3, P4, T3) ( $<<0.05)$ (Fig. 1). 


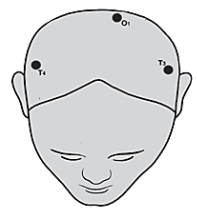

$\mathrm{R}$

high creativity

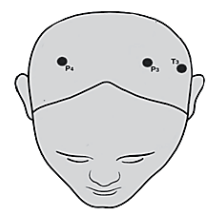

$\mathrm{R}$

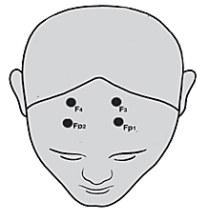

$\mathrm{R}$

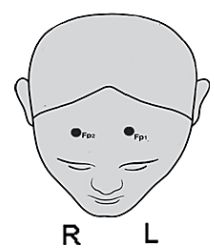

low creativity

Verbal converged task

average creativity

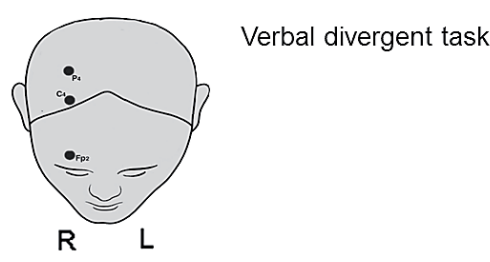

Figure 1. Statistically significant differences in the EEG power when comparing students of different creativity levels in solving problems of convergence and divergence $(p<0.05)$

The solution of a verbal divergent task by persons of high professional achievements is accompanied by power amplification in the back temporal zone, mainly of the right hemisphere, and the central frontal zone (T6, Fz); in those of average achievement level, the parietal central zones of the left hemisphere $(\mathrm{Pz})$ are amplified; in those of low achievement level, the frontal temporal zone of the right hemisphere $(\mathrm{T} 4)(\mathrm{p}<0.05)$ is amplified.

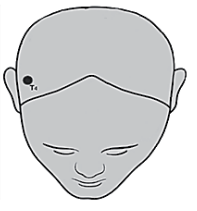

R L

High level of achievement

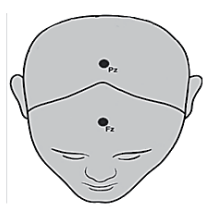

$\mathrm{R}$

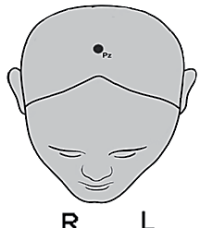

$\mathrm{R}$

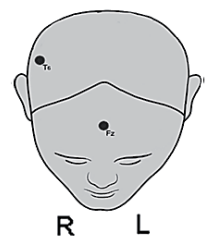

$\mathrm{R} \mathrm{L}$
Verbal converged task

The average level Low level of achievement of achievement

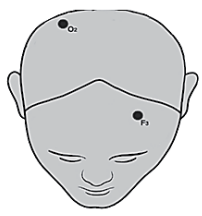

$\mathrm{R}$

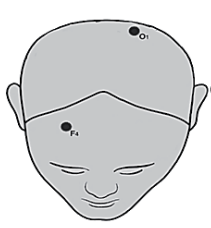

$\mathrm{R}$

Figure 2. Statistically significant differences in the EEG power when comparing students of different achievement levels in solving problems of convergence and divergence $(p<0.05)$

While solving a divergent task, the test subjects of high achievement level showed power amplification in the parietal central zone of the right hemisphere and the frontal central zone $(\mathrm{Pz}, \mathrm{Fz})$; in those of average achievement level, the occipital zone of the right hemisphere and the frontal zone of the left hemisphere 
(O2, F3) are amplified; in those of low achievement level, the occipital zone of the left hemisphere and the frontal zone of the right hemisphere $(\mathrm{O} 1, \mathrm{~F} 4)(\mathrm{p}<0.05)$ are amplified (Fig. 2).

It has been established that in individuals of low creativity and of mixed, right and left LAP, the localization of active brain zones is of a diffuse character, with a greater activity revealed in the occipital, central, and temporal zones of both hemispheres $(\mathrm{O} 1, \mathrm{O} 2, \mathrm{C} 3, \mathrm{C} 4, \mathrm{~T} 3, \mathrm{~T} 4)$. This is most obviously manifested in divergent task solutions $(\mathrm{p}<0.05)$. During average activity of young males and females (of the left and mixed LAP profiles), apart from the above named zones, the active zones become the central zones, which are particularly characteristic of the left and mixed profile representatives $(\mathrm{p}<0.05)$. Right LAP representatives revealed connections of a more localized character, yet in the verbal divergent task solution the picture was similar to the above described groups $(\mathrm{p}<0.05)$. Individuals of high creativity had a common tendency of including middle frontal and anterior frontal brain areas of both hemispheres. One should also note a lesser number of active zones in high creativity persons independent from LAP, which might be linked with a more effective cerebration, lower energy consumption, and the availability of definite cognitive schemes for a successful solution of the given task.

It has been shown that in young females and males of high creativity, the most significant power indices were higher in the parietal, temporal, and frontal brain regions $(\mathrm{P} 3, \mathrm{P} 4, \mathrm{~F} 3, \mathrm{~F} 4)(\mathrm{p}<0.05)$. In young males and females of the right LAP, the power was higher in the frontal and temporal zones of the left hemisphere (F3, T3), whereas in those with the left and mixed LAPs in the right or left hemisphere during divergent task solutions. In the solution of a convergent task, the power increased in the frontal, central, and occipital brain zones. However, the people with the right and mixed LAPs showed symmetrical power growth in the central brain zones $(\mathrm{C} 3, \mathrm{C} 4)(\mathrm{p}<0.05)$. The above tendency could be traced in high creativity young males and females, regardless of the level of their achievements.

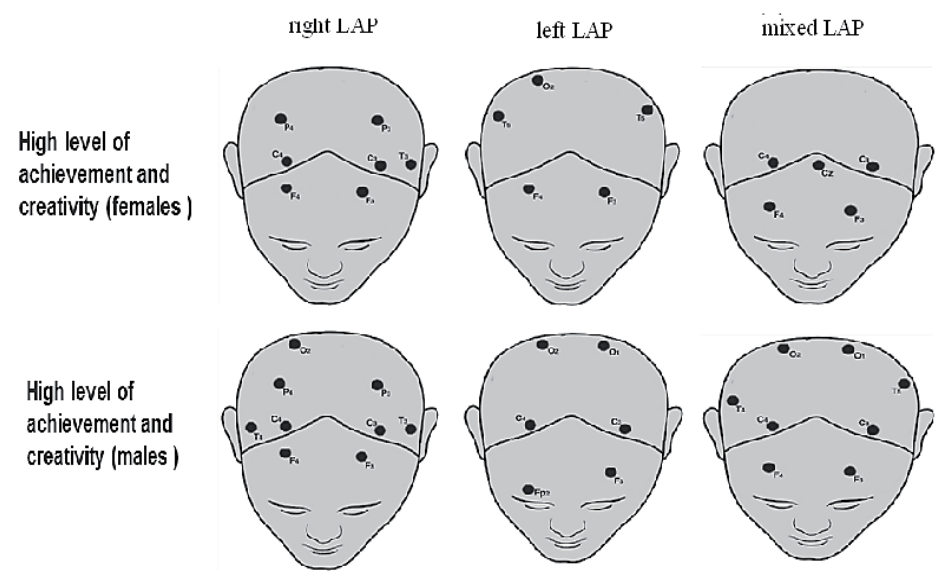

Figure 3. Statistically significant differences in the EEG power when comparing young males and females of different levels of achievement, creativity and LAP in solving problems of convergence and divergence $(p<0.05)$ 
In high creativity and average creativity young males and females of average and low achievement levels, as they solved a convergent task, power growth was not localized, yet diffusely distributed among the central, frontal, parietal zones of both hemispheres (C4, C3, F3, F4, P3, P4). In young people with high achievements, asymmetrical brain zones power increased during a divergent task solution, which fact speaks in favor of intensive interhemispheric interaction. It is characteristic that young males and females with the right LAP, high creativity and achievement level in the solution of the given tasks, engage more symmetrical brain zones $(\mathrm{p}<0.05)$. (Fig. 3).

\section{Conclusions}

The assessment of the psychophysiological mechanisms of the cognitive component in social activity has shown that the peculiarities of divergent and convergent thinking in young males and females of various levels of creativity and professional success are stipulated by a definite picture of hemispheric activation. In the solution of a verbal divergent task by young males and females of high creativity and professional achievement, the frequency-spatial EEG indices are higher in the parietal and frontal brain regions. In the solution of a convergent task, these are higher in the frontal, central, and cervical brain zones. In cases of young males and females of low creativity and average and low levels of professional achievement, the solution of a convergent task is accompanied by increased EEG power in the central, frontal, parietal zones of both hemispheres.

While studying, young people of a high creativity level demonstrate better results in both their research activities and social life.

This difference, revealed at the initial stage of the investigation, demands further study of the social creativity phenomenon in the professional training of a personality inclusive of this personality's individual peculiarities.

\section{Acknowledgements}

This study was funded by The Ministry of Education and Science of the Russian Federation, grant no 25.2141.2014/K.

\section{References}

Abra, J., \& Valentine-French, S. (1991). Gender differences in creative achievement: a survey of explanations. Genetic, Social and General Psychology Monographs, 117(3), 235-284.

Akhmetova L. V. (2010). Sotsialno-psikhologicheskaya adaptatsiya i professionalnoye razvitiye lichnosti v pedagogicheskom vuze [Social and psychological adjustment and professional development of personality in a pedagogical university]. Vestnik Tomskogo gosudarstvennogo pedagogicheskogo universiteta [Tomsk State Pedagogical University Bulletin], 4, 131-135.

Banyukhova, A. Ye. (2011). Psikhologicheskiye aspekty razvitiya sotsialnoy kreativnosti studentov [Psychological aspects of development of social creativity in students]. Vestnik Tomskogo gosudarstvennogo pedagogicheskogo universiteta [Tomsk State Pedagogical University Bulletin], 6, 199-203.

Chan, D. W. (2005). Self-perceived creativity, family hardiness, and emotional intelligence of Chinese gifted students in Hong Kong. Journal of Secondary Gifted Education, 16, 47-56. 
Kaufman, J. C., Baer, J., Agars, M.D., \& Loomis, D. (2010). Creativity stereotypes and the consensual assessment technique. Creativity Research Journal, 22(2), 200-205. doi: $10.1080 / 10400419.2010 .481529$

Ilyinykh, A. Ye. (2011). Sotsialnaya kreativnost lichnosti: Psikhologicheskaya struktura [Social creativity of a personality: Psychological structure]. Izvestiya Saratovskogo universiteta. Ser. Filosofiya. Psihologiya. Pedagogika [Saratov University Bulletin. Series in Philosophy, Psychology and Education], 5(11), 74-77.

Kann, S. Yu. (1997). Izuchenie vzaimosvyazi kreativnosti obshcheniya i kreativnosti myshleniya studentov [Research of links between creativity in communication and creativity in thinking at the sample of students]. (Unpublished doctoral dissertation). Russia, Ryazan.

Kaufman, J. C. (2006). Self-reported differences in creativity by gender and ethnicity. Journal of Applied Cognitive Psychology, 20(8), 1065-1082.doi: 10.1002/acp.1255

Osipova, T. Yu. (2000). Psikhologicheskie usloviya razvitiya kommunikativnoy kreativnosti u studentov tekhnicheskikh vuzov (na materialakh speckursa "Psikhologiya obshcheniya") [Psychological conditions for development of communicative creativity in STEM students (at the materials of "Communication Psychology" course)]. (Unpublished doctoral dissertation). Russia, Tomsk.

Popel, A. A. (2005). Psikhologicheskie usloviya razvitiya sotsialnoy kreativnosti studentov $v$ protsesse professionalnoy podgotovki [Psychological conditions for development of communicative creativity in students in the course of professional education]. (Unpublished doctoral dissertation). Russia, Nizhniy Novgorod.

Runco, M. A., \& Bahleda, M. D. (1986). Implicit theories of artistic, scientific and everyday creativity. Journal of Creative Behavior, 20, 93-98. doi: 10.1002/j.2162-6057.1986.tb00423.x

Tyurmina, N. A. (2004). Kreativnost v sfere obshcheniya: Psikhologicheskie osobennosti, usloviya formirovaniya $v$ podrostkovom vozraste [Creativity in communication: Its psychological peculiarities and conditions for development during adolescence]. (Unpublished doctoral dissertation). Russia, Kazan.

Original manuscript received July 19, 2015

Revised manuscript accepted October 08, 2015

First published online December 30, 2015 